\title{
RADIONUCLIDES IN FISH OF THE CHERNOBYL EXCLUSION ZONE: SPECIES-SPECIFICITY, SEASONALITY, SIZE- AND AGE-DEPENDENT FEATURES OF ACCUMULATION*
}

\author{
A.Ye. Kaglyan ${ }^{* * 1}$, D.I. Gudkov', V.G. Klenus', L.P. Yurchuk1, A.B. Nazarov², \\ N.A. Pomortseva1 , Z.O. Shirokaya1, N.L. Shevtsova1 \\ ${ }^{1}$ Institute of Hydrobiology, Kyiv, Ukraine \\ ${ }^{2}$ Chernobyl Specialized Enterprise, Chernobyl, Ukraine
}

\begin{abstract}
The results of studies during 2006-2013 of fish from 12 water bodies with different hydrological mode and levels of radioactive contamination within the Chernobyl exclusion zone are presented. The specific activity of 90 Sr and ${ }^{137 C s}$ for 17 species of fish, concerning various ecological groups was estimated. The fish of stagnant water bodies of the Chernobyl exclusion zone continue to be characterized by the high concentration of ${ }^{90}$ Sr and ${ }^{137 C s . ~ R a d i o n u c l i d e}$ specific activity in fish of closed water bodies of the Chernobyl exclusion zone during our studies in all cases exceeded maximal permissible levels, according to the standards, accepted in Ukraine for fish production: in 53-2892 times on

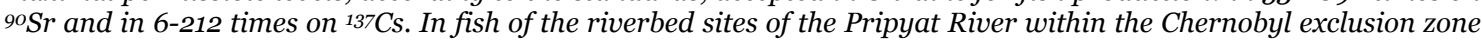

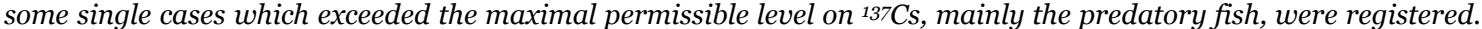
The analysis of radionuclide specific activity data in fish of various size, weight and age groups on an example of the common rudd and the European perch from Glubokoye Lake has allowed the revelation of a dependence of 90 Sr and ${ }^{137 C s}$ accumulation on the weight of body and the age of fishes.
\end{abstract}

Key words: Chernobyl exclusion zone, radioactive contamination, aquatic ecosystems, fish, ${ }^{\circ 0} \mathrm{Sr},{ }^{137 \mathrm{Cs}}$

DOI: $10.21175 / \operatorname{RadJ} .2016 .02 .020$

\section{INTRODUCTION}

Radionuclide migration in river systems' basins is mainly determined by the dynamics of hydrological and biochemical processes of substances turnover in the environment. Along with the deposition of radionuclides in the bottom sediments by way of sedimentation and sorption and their precipitating together with suspended matter, there is another important process of radionuclide distribution in freshwater ecosystems, namely their accumulation by hydrobionts. The special attention in this issue is paid to fish, occupying the upper trophic levels in aquatic biocenosis and routinely caught and ingested as a source of food.

The aim of our studies was the estimation of the main dose-forming radionuclide $\left({ }^{137} \mathrm{Cs}\right.$ and $\left.{ }^{90} \mathrm{Sr}\right)$ accumulation by fish species of different ecological groups within the Chernobyl exclusion zone (ChEZ) as well as the determination of seasonality, size- and agedependent features of radionuclide concentration.

\section{MATERIALS AND METHODS}

The material was represented by fishes, sampled during 2006-2013 from 12 water bodies with different hydrological regime and level of radioactive contamination within the ChEZ. Depending upon water exchange intensity the water bodies were divided into six conventional groups: (1) closed lakes (lakes
Vershina, Glubokoye, Azbuchin and Dalekoye); (2) water body with slow water exchange (Chernobyl NPP cooling pond); (3) relatively closed water bodies (Yanovsky and Novoshepeletsky crawls, Krasnensky former river bed within inside section of the dam constructions); (4) slow flowing water body (Krasnensky former river bed within outside section of the dam constructions, that has a channel connection with the Pripyat River); (5) open crawls of the Pripyat River (Schepochka and Pripyatsky) and (6) flowing water object (the Pripyat River).

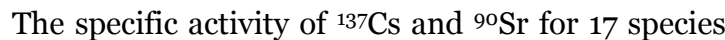
of fish, concerning the various ecological groups, was analyzed by the methods [1]. The radionuclide specific activity was measured for a whole fish body. For ${ }^{137 \mathrm{Cs}}$ specific activity the error of measurement (confidence intervals) made up about $15 \%$, and for ${ }^{\circ} \mathrm{Sr}$ specific activity - 20\% [2]. We have also developed a rapid method of the specific activity of ${ }^{137 \mathrm{Cs}}$ and ${ }^{90} \mathrm{Sr}$ determination in fish on their content in scales and fins $[3,4]$. At the same time the fish was staying alive. The research data were processed statistically with the help of computing software Microsoft Excel 2007, Statistica $5 \cdot 5$.

Among predatory fish (obligate and facultative ichthyophagous), the fish that were analyzed were pikeperch Sander lucioperca L. (trophic level (TL) 4.0 - http://fishbase.org ), Wels catfish Silurus glanis L. (TL 4.4), chub Leuciscus cephalus L. (TL 2.7), asp Aspius aspius L. (TL 4.5), pike Esox luceus L. (TL 4.1), European perch Perca fluviatilis L. (TL 4.4) and razor fish Pelecus cultratus L. (TL 3.6). Among prey fish, we

\footnotetext{
* The paper was presented at the Third International Conference on Radiation and Applications in Various Fields of Research (RAD 2015), Budva, Montenegro, 2015.
} 
studied zooplanktonophagous as blue bream Ballerus ballerus L. (TL 3.2) and bleak Alburnus alburnus L. (TL 2.7); bentophagous as crucian carp Carassius carassius L. (TL 3.1), Prussian carp Carassius gibelio Bloch (TL 2.5), bream Abramis brama L. (TL 3.1), silver bream Blicca bjoerkna L. (TL 3.2), tench Tinca tinca L. (TL 3.7), roach Rutilus rutilus L. (TL 3.0), common carp Cyprinus carpio L. (TL 3.1), and also phytophagous as common rudd Scardinius erythrophthalmus L. (TL 2.9). The age of fishes varied between 1 and 12 years. The absorbed dose rate for fishes was estimated with the help of the software package [5].

\section{RESULTS AND CONCLUSIONS}

The specific activity of ${ }^{137} \mathrm{Cs}$ and ${ }^{90} \mathrm{Sr}$ in predatory fish species of the Pripyat River ( $6^{\text {th }}$ group) during the survey period made up respectively: 22-224 $\mathrm{Bq} \mathrm{kg}^{-1}$ (here and further on the specific activity is given per one kilogram of wet weight) and $1-16 \mathrm{~Bq} \mathrm{~kg}^{-1}$, and in prey fish species - 12-60 and $3-13 \mathrm{~Bq} \mathrm{~kg}^{-1}$. In the Schepochka and Pripyatsky crawls ( $5^{\text {th }}$ group) the

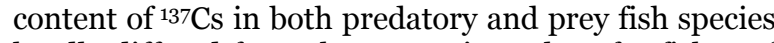
hardly differed from the respective values for fishes of the Pripyat River; however, the concentration of ${ }^{\circ} \mathrm{Sr}$ in ichthyophagous was considerably higher - 11$119 \mathrm{~Bq} \mathrm{~kg}^{-1}$, and in pray fishes - 41-221 $\mathrm{Bq} \mathrm{kg}^{-1}$.

The utmost values of ${ }^{\circ} \mathrm{Sr}$ specific activity exceeded more than 6 times the permissible level $(P L)$ of this radionuclide for fish products in accordance with the current Ukrainian standards: $150 \mathrm{~Bq} \mathrm{~kg}{ }^{-1}$ for ${ }^{137} \mathrm{Cs}$ and $35 \mathrm{~Bq} \mathrm{~kg}^{-1}$ for ${ }^{90} \mathrm{Sr}$ [6]. The higher levels of radionuclide specific activity, determined in fish of the Krasnensky former river bed ( $4^{\text {th }}$ group) $-459-11204 \mathrm{~Bq} \mathrm{~kg}^{-1}$ of ${ }^{137 \mathrm{Cs}}$ and $97-3179 \mathrm{~Bq} \mathrm{~kg}^{-1}$ of ${ }^{\circ} \mathrm{Sr}$, are registered. As regards the fish fauna of the Yanovsky Crawl and Krasnensky former Pripyat River bed ( $3{ }^{\text {rd }}$ group), the content of ${ }^{137 \mathrm{Cs} \text { and }}{ }^{90} \mathrm{Sr}$ in prey fish species exceeded the PL respectively 2.3-22.6 and 24.8-333.1 times, and in predatory species the exceeding made up respectively 6.8-31.7 and 17.9-235.0 time. In the fish of the cooling pond (the $2^{\text {nd }}$ group) ${ }^{137 \mathrm{Cs}}$ content was registered to exceed the $P L$ 4.6-72.7 times, and ${ }^{90} \mathrm{Sr}$ - only 1.2-21.7 times, which was associated with the increased flowage of this water body [7-11]. Even more contaminated with radionuclides is the fish fauna in lakes Glubokoye, Azbuchin, Dalekoye and Vershina (the $1^{\text {st }}$ group), where the specific activity of ${ }^{137 \mathrm{Cs}}$ and ${ }^{90} \mathrm{Sr}$ are registered in pray fishes, respectively, 440-31859 and 2490-101217 Bq kg-1, and in predatory fishes - 173022030 and 1489-15584 $\mathrm{Bq} \mathrm{kg}^{-1}$.

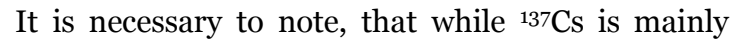
accumulated in the muscular tissue of fish, almost all amount of ${ }^{90} \mathrm{Sr}$ is concentrated in its inedible bone tissue - scales and skeleton. The ${ }^{90} \mathrm{Sr} /{ }^{137} \mathrm{Cs}$ ratio in predatory fishes of the Pripyat River made up 0.060.52 , and in prey fishes - 0.15-0.37 was represented (fig. 1).

In the Schepochka Crawl, such ratio for ichthyophagous reached $0.25-1.33$, and for prey fish species - rose to 1.01-2.46. In the cooling pond, the ${ }^{90} \mathrm{Sr} /{ }^{137} \mathrm{Cs}$ ratio for all studied fish species was less than
1 and varied between 0.02 and 0.38 . In the closed Yanovsky and Novoshepeletsky crawls, Krasnensky former river bed within inside and outside sections of the dam constructions, lakes Glubokoye, Vershina, Azbuchin, Dalekoye, the ${ }^{90} \mathrm{Sr} /{ }^{137} \mathrm{Cs}$ specific activity ratio in prey fish species attained as much as 1.7850.00, and in predatory fish - 0.38-2.11.

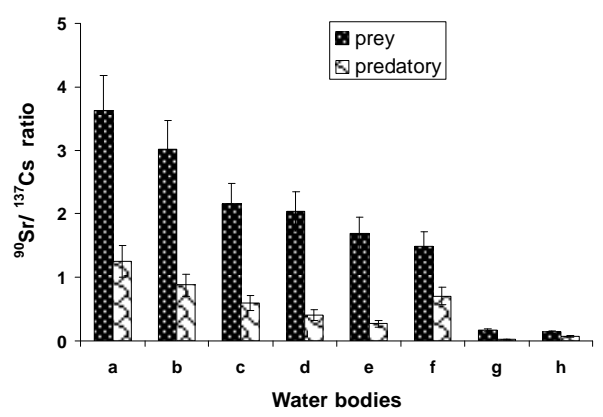

Figure 1. ${ }^{90} \mathrm{Sr} /{ }^{137 \mathrm{Cs}}$ ratio in prey and predatory fish species of water bodies in the ChEZ: (a) Krasnensky former river bed within inside section of the dam constructions; (b) Glubokoye Lake; (c) Yanovsky Crawl; (d) Azbuchin Lake; (e) Krasnensky former river bed within outside section of the dam constructions; (f) Schepochka Crawl; (g) Chernobyl NPP cooling pond and (h) the Pripyat River

Besides, the Pripyatsky Crawl and former river beds with slow water exchange probably accumulate soluble, biologically available forms of ${ }^{90} \mathrm{Sr}$, which at present still come from the radionuclide-contaminated catchment area and are involved in the biogeochemical circulation of matter, concentrating in the biotic components of water ecosystems.

Our own survey has confirmed that in most of lotic

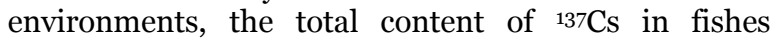
significantly exceeds this value for ${ }^{90} \mathrm{Sr}$, which complies with the traditional concept of the ratio of radionuclides, which came to water bodies with global precipitations. However, such pattern is not always observed in fishes of the slow running rivers' sections within the ChEZ borders, which are distinguished by the particular ratio of physical and chemical radionuclide forms, caused by accidental emissions [ 1 , $8,12]$.

Almost in all the surveyed water bodies of the ChEZ the most abundant species, also marked by high radionuclide accumulation levels, include the common rudd as the prey fish species and the European perch as the predatory fish species. These species can be considered to be the reference species and the most prospective ones for radio-ecological monitoring of the ChEZ freshwater ecosystems and for estimating the level of fish fauna contamination by ${ }^{\circ} \mathrm{Sr}$ and ${ }^{137 \mathrm{Cs}}$ [13].

Analysis of data obtained during 2007-2013 indicates that the specific activity of ${ }^{137 \mathrm{Cs} \text { and }}{ }^{90} \mathrm{Sr}$ in the ichthyofauna of almost all water bodies of the ChEZ continues to decline gradually. The exceptions are closed water bodies, located on the territory of the left bank dammed floodplain of the Pripyat River (Glubokoye Lake, Vershina Lake etc.), where with a gradual decrease of ${ }^{137} \mathrm{Cs}$ and ${ }^{90} \mathrm{Sr}$ specific activity in ichthyophagous fish, the reduction of both radionuclides in prey fish occurs much more slowly or 
is not observed at all (fig. 2 and 3). The seasonal dynamics in accumulation by representatives of prey and predatory fish species, with maximum values of radionuclide concentrations during the summer period, is determined.

In order to survey radionuclide accumulation by different age groups of fishes in the closed water bodies of the ChEZ, 100 samples of the common rudd and the European perch were taken from Glubokoye Lake. The age groups consisted of 3-20 specimens.

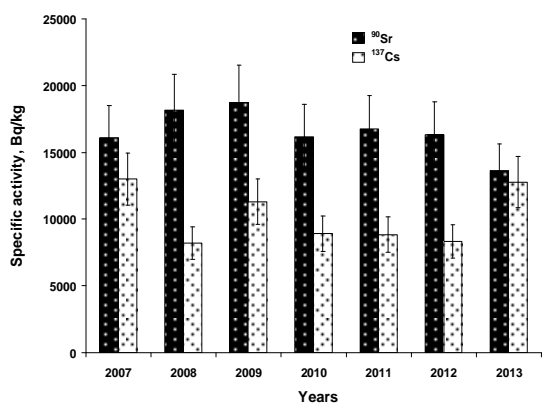

Figure 2. Dynamics of average annual specific activity of radionuclides for prey fish species (the common rudd as example) in Glubokoye Lake

Evaluation of radionuclide specific activity in fishes of different size and weight groups made it possible to find that ${ }^{90} \mathrm{Sr}$ and ${ }^{137} \mathrm{Cs}$ accumulation depend upon the body weight of the common rudd and the European perch in Glubokoye Lake (fig. 4 and 5).

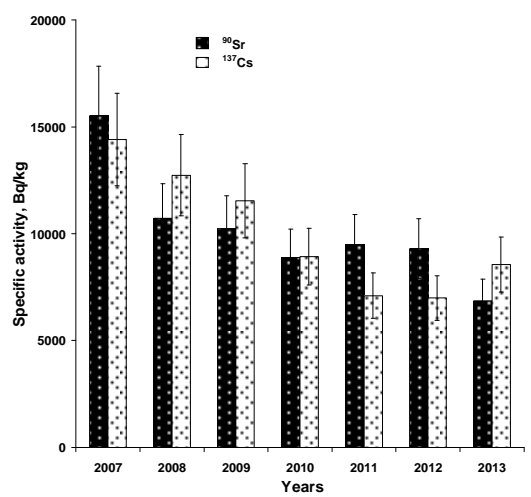

Figure 3. Dynamic of average annual specific activity of radionuclides for predatory fish species (the European perch as example) in Glubokoye Lake

More intensive accumulation of radionuclides in the early periods of fish life is rather marked. The approximation of the obtained data, with the statistical significance being comparatively low, makes it possible though to detect specific differences in dynamics of radionuclide accumulation by non-predator and predator fish species with their size and weight parameters increasing. These peculiarities are most significantly marked and have high approximation reliability in the fish age - radionuclide accumulation relation (fig. 5). The typical increase in ${ }^{90} \mathrm{Sr}$ and ${ }^{137} \mathrm{Cs}$ specific activity has been observed in the common rudd with preferred ${ }^{90} \mathrm{Sr}$ accumulation, evidently, at the early stages of its postembryonic ontogenesis. As regards the European perch, higher ${ }^{90} \mathrm{Sr}$ content

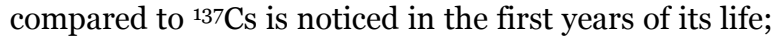
however; in the following years, probably with gradual prevalence of small fish in its feeding, ${ }^{137 \mathrm{Cs}}$ specific activity begins to exceed that of ${ }^{9} \mathrm{Sr}$, which accumulation, on the contrary, slows down with age.

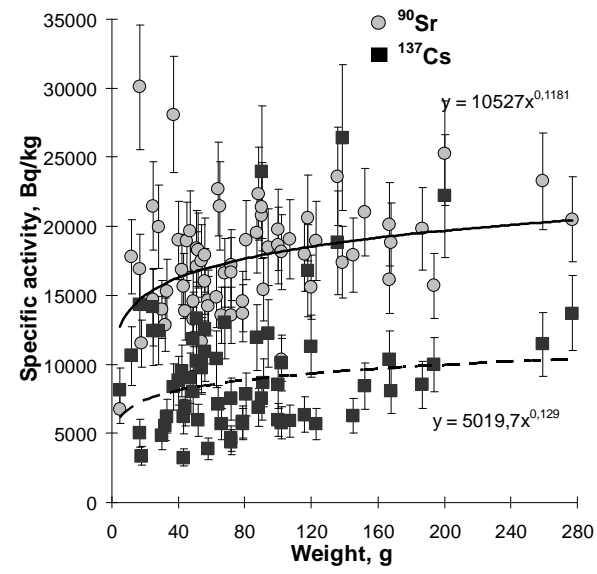

Figure 4. Weight dynamics of radionuclide specific activity for the common rudd in Glubokoye Lake

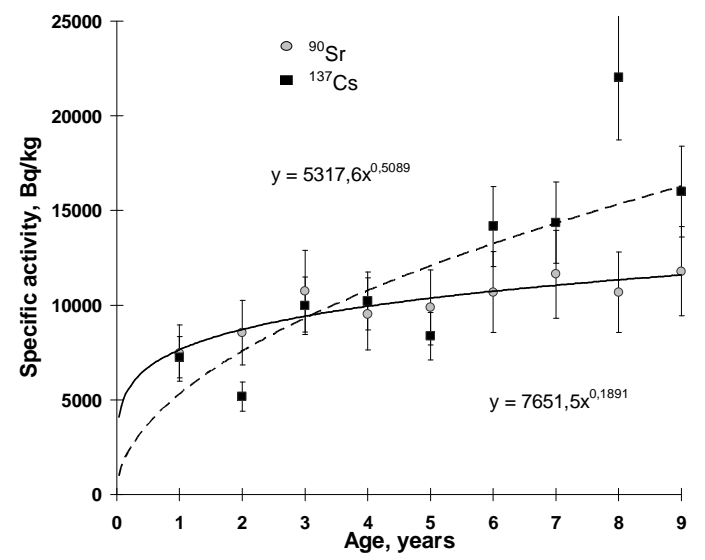

Figure 5. Age dynamics of radionuclide specific activity for the European perch in Glubokoye Lake

The absorbed dose rate estimation showed that the highest radiation doses in the ChEZ water bodies are obtained by fishes inhabiting the lake ecosystem, where this value for different fish species varies between 13.0 (pelagic species) to 294.o (bottom species) $\mu \mathrm{Gy} \mathrm{h} \mathrm{h}^{-1}$.

The internal dose contribution by the incorporated radionuclides changes from 3.6 to $33.2 \%$ of the total radiation dose. The incorporated ${ }^{90} \mathrm{Sr}$ contributions into the internal radiation dose make up 87.1-94.5\% for pray fish and $70.8-78.5 \%$ for predatory fish. In the Pripyat River the absorbed dose rate makes up 0.0110.013 for pelagic fish species and 0.023-0.042 $\mu \mathrm{Gy} \mathrm{h} \mathrm{h}^{-1}$ for bottom species.

Therefore, the natural self-purification processes in the reservoirs within the ChEZ are extremely slow, which causes the specific activity of the main doseforming radionuclides in fish species of the majority of lakes, former river beds and crawls to remain at quite a high level. The radionuclides content in fishes of the 
Pripyat River is considerably lower than the permissible levels, being in force in Ukraine, and only in several cases exceeds these values insignificantly (mainly in predatory fishes).

The ${ }^{90} \mathrm{Sr}$ content in fishes of the slowly flowing Schepochka Crawl exceeds the $P L$ in 2-3 times at an average. The radionuclide specific activity in fish of the Yanovsky and Novoshepeletsky crawls, Krasnensky former river bed within inside and outside sections of the dam constructions, lakes Glubokoye, Vershina, Azbuchin, Dalekoye exceeds the $P L$ in 3-212 times for

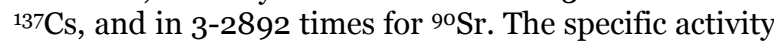
of ${ }^{90} \mathrm{Sr}$ и ${ }^{137} \mathrm{Cs}$ in prey fishes (as it can be seen for rudd in Glubokoye Lake) rises approximately in 1.7 and 1.5 times with the fish age increasing from 1 to 9 years, and in predator fishes (as it can be seen for perch in Glubokoye Lake) $-{ }^{\circ} \mathrm{Sr}$ rises in 1.4 times, and ${ }^{137 \mathrm{Cs}-}$ up to 3.0 times by the $9^{\text {th }}$ year of life. Such fish species as rudd and perch can be used as indicators of radioactive contamination of water-bodies by ${ }^{\circ} \mathrm{Sr}$ and ${ }^{37} \mathrm{Cs}$ respectively. The total absorbed dose range in fishes of lakes Glubokoye and Vershina made up 13.0294.0, Yanovsky Crawl - 1.60-27.7, Schepochka Crawl 0.04-0.12 and the Pripyat River - 0.01-0.04 $\mu \mathrm{Gy} \mathrm{h}{ }^{-1}$.

In the majority of Ukrainian water bodies, located outside the ChEZ borders, this value does not exceed $0.01 \mu \mathrm{Gy} \mathrm{h}^{-1}$. Taking into account that for fishes of closed, relatively closed and slowly flowing water bodies, ${ }^{\circ} \mathrm{Sr}$ is responsible for more than a half of the total internal absorbed dose rate, we can come to a conclusion that ${ }^{90} \mathrm{Sr}$ is the main dose-forming radionuclide for fish in the majority of water bodies within ChEZ at present.

Acknowledgement: This study was supported by the National Academy of Sciences of Ukraine and by the State Agency of Ukraine on the Exclusion Zone Management (Projects No o111Uoooo76 and o113Uooo933). The authors wish to thank the personnel of the Chernobyl Nuclear Power Plant and Chernobyl Specialized Enterprise for the promoting research within the ChEZ. We also thank employee of the Institute of Hydrobiology for the radionuclide measuring procedure and ichthyologic analysis.

\section{REFERENCES}

1. M.I. Kuzmenko, D.I. Gudkov, S.I. Kireyev et al., Technogenic radionuclides in freshwater ecosystems. Kyiv, 2010. (in Ukrainian).

2. Measurement of radionuclides' volume activity by gamma-spectrometry method with high resolution ratio. State Standard of Ukraine ISO 10703-2001-Kyiv: State Committee for Technical Regulation and Consumer Policy of Ukraine, 2003, 15 p. (in Ukrainian).

3. A.Ye. Kaglyan, D.I. Gudkov, Patent UA №106547, Ukraine, GO1T 1/16 (2006.01) "Method of assessment of specific activity of radionuclides in organs and tissues of fishes on the basis of their concentration in scale”, Bulletin, No 17, 2014 (in Ukrainian).

4. A.Ye. Kaglyan, D.I. Gudkov, V.G. Klenus et al., Patent UA №107611, Ukraine, GO1T 1/16 (2006.01) "Method of assessment of specific activity of radionuclides in organs and tissues of predator fishes (Percidae and Esocidae families) on the basis of their concentration in fins”, Bulletin, №2, 2015 (in Ukrainian).

5. ERICA Assessment Tool 1.o. The integrated approach seeks to combine exposure/dose/effect assessment with risk characterization and managerial considerations (Version November 2012) (http://www.erica-tool.com).

6. Ministry of Health Protection of Ukraine, National Commission for Radiation Protection of Ukraine committee " $137 \mathrm{Cs}$ и ${ }^{90} \mathrm{Sr}$ content permissible levels in food products and drinking water (PL-97)”, Kyiv, 1997. (in Ukrainian).

7. D.I. Gudkov, M.I. Kuzmenko, S.I. Kireyev et al., "Radionuclides in Components of Aquatic Ecosystems of the Chernobyl Accident Restriction Zone" in 20 Years after the Chernobyl Accident: Past, Present and Future. E.B. Burlakova, V.I. Naidich, Eds. New York: Nova Science Publishers, 2006, pp. 265-285.

8. D.I. Gudkov et al., "Patterns of the main dose-forming radionuclides accumulation by fish in the water bodies within the exclusion zone", Chernobyl Scientific Journal, The Exclusion Zone Ecological State Bulletin, №2, 2007, pp. 34-43 (in Ukrainian).

9. D.I. Gudkov et al., "Dynamics of content and distribution of the main dose-forming radionuclides in fishes of the Chernobyl NPP exclusion zone", Hydrobiological Journal, 2008, №3, pp. 95-113. (in Russian).

10. A.Ye. Kaglyan et al., "Present-day radionuclide contamination of freshwater fishes of Ukraine". Reports of the National Academy of Sciences of Ukraine, №12, 2011, pp. 164-170. (in Ukrainian).

11. A. Kaglyan et al., "Radionuclide contamination of freshwater fishes after the CNPP accident", Twenty five years of the Chernobyl disaster. Security of the Future, Kyiv, April 2011, part 2, pp. 301-306 (in Ukrainian)

12. A.Ye. Kaglyan et al., "Radionuclides in the native fish species of the Chernobyl exclusion zone", Nuclear Physics and Energy, №3, 2012, pp. 306-315 (in Russian).

13. A.Ye. Kaglyan, D.I. Gudkov, V.G. Klenus et al., Patent UA No 95746, Ukraine, GO1T 1/16 (2006.01) "Method of estimation of the maximal radionuclide contamination level of the freshwater fish fauna", Bulletin, No 16, 2011 (in Ukrainian). 